\title{
ARE COMPETENCIES AND CORPORATE STRATEGY ALIGNED? AN EXPLORATORY STUDY IN BRAZILIAN STEEL MILLS
}

\begin{abstract}
In this qualitative and exploratory study, a measurement of alignment of competencies with corporate strategy was carried out in nine steel mills, using a methodology developed specifically for this purpose. The combined revenue of the companies in the sample represents almost the entire Brazilian steel market (97\%). Four companies ("big and aligned"), accounting for $82 \%$ of the steel produced in the country, indicate full alignment of competencies with their strategies. Two companies ("small and partially aligned"), represent $4 \%$ of the market and try to reconcile the corporate strategy of technological orientation with short-term operational performance imposed on them by the business environment. In contrast to the latter, three companies ("small and not aligned"), having $11 \%$ of the combined market share, primarily concern themselves with performance in terms of productivity, without having synergy with the corporate strategy. The major contribution of this work is the development of a specific methodology to operationalize the mapping of core competencies, in order to facilitate the mobilization of resources to support business strategies.
\end{abstract}

Keywords: Core Competencies; Mapping Competencies; Corporate Strategy; Alignment of Critical Resources; Resource-Based View of the Firm.

\section{AS COMPETÊNCIAS E A ESTRATÉGIA CORPORATIVA ESTÃO ALINHADAS? UM ESTUDO EXPLORATÓRIO EM FABRICANTES DE AÇO NO BRASIL}

\section{RESUMO}

Neste estudo qualitativo e exploratório, foi realizada uma medição do alinhamento de competências com a estratégia corporativa em nove usinas siderúrgicas, utilizando uma metodologia desenvolvida especificamente para esse fim. A receita combinada das empresas na amostra representa quase todo o mercado siderúrgico brasileiro (97\%). Quatro empresas ("grandes e alinhadas"), que representam $82 \%$ do aço produzido no país, indicam o alinhamento total das competências com suas estratégias. Duas empresas ("pequenas e parcialmente alinhadas") representam 4\% do mercado e tentam conciliar a estratégia corporativa de orientação tecnológica com o desempenho operacional de curto prazo que lhes é imposto pelo ambiente empresarial. Em contraste com este último, três empresas ("pequenas e não alinhadas"), com $11 \%$ da quota de mercado combinada, se preocupam principalmente com o desempenho em termos de produtividade, sem ter sinergia com a estratégia corporativa. A principal contribuição deste trabalho é o desenvolvimento de uma metodologia específica para operacionalizar o mapeamento de competências essenciais, a fim de facilitar a mobilização de recursos para apoiar estratégias de negócios.

Palavras-chave: Competências Essenciais; Mapeamento de Competências; Estratégia Corporativa; Alinhamento de Recursos Críticos; Visão da Empresa Baseada em Recursos. 


\section{¿ESTÁN ALINEADAS LAS COMPETENCIAS Y LA ESTRATEGIA EMPRESARIAL? UN ESTUDIO EXPLORATORIO EN COMPAÑÍAS DE ACERO BRASILEÑAS}

\section{RESUMEN}

En este estudio cualitativo y exploratorio, se llevó a cabo una medición de alineación de competencias con la estrategia corporativa en nueve fábricas de acero, utilizando una metodología desarrollada específicamente para este propósito. Los ingresos combinados de las empresas de la muestra representan casi la totalidad del mercado brasileño de acero (97\%). Cuatro compañías ("grandes y alineadas"), que representan $82 \%$ del acero producido en el país, indican la alineación completa de las competencias con sus estrategias. Dos empresas ("pequeñas y parcialmente alineadas") representan $4 \%$ del mercado e intentan conciliar la estrategia corporativa de orientación tecnológica con el rendimiento operativo a corto plazo impuesto por el entorno empresarial. En contraste con este último, tres empresas ("pequeñas y no alineadas"), que tienen $11 \%$ de la cuota de mercado combinada, se preocupan principalmente con el rendimiento en términos de productividad, sin tener una sinergia con la estrategia corporativa. La principal contribución de este trabajo es el desarrollo de una metodología específica para operacionalizar el mapeo de las competencias esenciales, a fin de facilitar la movilización de recursos para apoyar las estrategias comerciales.

Palabras clave: Competencias Esenciales; Mapeo de Competencias; Estrategia Corporativa; Alineación de Recursos Críticos; Visión de la Empresa Basada en Recursos.

\footnotetext{
${ }^{1}$ Mestre em Gestão e Tecnologia Industrial pelo Senai/Cimatec. Brasil. E-mail: Ualace.Porto@graftech.com

2 Doutor em Administração pela Universidade de São Paulo - USP. Professor da Faculdade de Tecnologia SENAI/CIMATEC. Brasil. E-mail: francisco.uchoa@fieb.org.br

${ }^{3}$ Doutor em Business Administration pela Boston University School of Management, Estados Unidos. Professor da Universidade Federal da Bahia - UFBA. Brasil. E-mail: paulo_s_figueiredo@hotmail.com
} 


\section{INTRODUCTION}

For a company to enjoy sustainable, competitive advantage in its business environment, it is argued that it should have specific (tangible and intangible) resources and master certain skills that, collectively, became known as its "core competencies" (Prahalad \& Hamel, 1990). Such belief - derivative of the school of thought known as "resource-based view" - has been long shared by several authors focused in understanding business strategies (Penrose, 1959; Wernerfelt, 1984; Barney, 1991; 1995).

Despite having a robust concept and a narrative of easy persuasion, the core competencies of a company do not always get an operationalization that explores their full potential. First, it is a real challenge to accurately identify them, since there is a lack of objective methodologies to perform this task (Hafeez, Zhang \& Malak, 2002). Since they are often not clearly identified, it becomes difficult to assemble such competencies to benefit the competitive position of the business.

However, even when core competencies are identified, another challenge faced by managerial practice is to mobilize them in the direction of the corporate strategy. The issue of aligning the competencies with strategy deserves attention, and some published works state that core competencies aligned with organizational strategies have the potential to promote results that benefit the business' competitive advantage (Grant, 1991; Danilovic \& Leisner, 2007).

This multiple case study is an exploratory research and attempts to identify core competencies, as well as check their alignment with corporate strategy, on a sample of the nine most important companies of the Brazilian steelmaking industry. The moment seems appropriate for such a research, in view of the struggles faced by this industry (Newspaper "Estado de S. Paulo", 11/27/2015 and 01/02/2016; Newspaper "Valor Econômico", 01/28/2016). The situation is pressing due to the importance of the steelmaking industry for the socio-economic development of the country, since for each job created in the steel Brazilian industry, another 23 are created in the economy, which means, currently, around 3.3 million working positions (Instituto Aco Brasil, 2015). The arrival of newcomers in the world steel market, particularly China since the early 2000's, as well as the corporate merger and acquisition processes that generated great global steelmaking conglomerates, have been weakening the Brazilian steelmaking industry. The reaction from part of the sector has been almost innocuous so far, focused mainly on conventional measures to reduce costs and attempts to increase productivity, practices that are currently wide-spread in the industry, and that, per se, do not ensure sustainable competitive advantage anymore (Crosseti \& Fernandes, 2005).
Although many studies on core competencies focus on businesses of advanced technology, the firms studied here also seem appropriate. It is understood that nowadays even an industry whose technology is deemed traditional, such as the steelmaking industry, may develop competencies with the same basic features as those described by Prahalad \& Hamel (1990). We refer to competencies that are "not necessarily disruptive, but incrementally built over time, and with potential to generate several types of products intended for different markets". Indeed, processes of the modern steel industry begin to appear in Brazil, with potential to develop competencies aimed at the creation of products of high added value and wide application in multiple markets. Mentioning only one example among many, there is the case of the high precision rolling of very thin and strong plates, for use in especial products, such as wind generator blades and other structural items that require high strength and low weight.

Based on the premise that core competencies, aligned with the business strategy, would result in competitive advantage (Grant, 1991; Danilovic \& Leisner, 2007), the purpose of this work is justified, which is to answer the following question: to what extent are the core competencies of Brazilian steelmaking companies aligned with their strategies?

To execute such a task, the competencies of the firms in the sample were listed using the Hafeez; Zhang; Malak (2002) model, and a method of operationalizing it and tailoring it to steelmaking companies was proposed, by means of a square matrix that reflects the alignment of core competencies with the respective strategies of the companies.

This paper comprises the following sections: this introductory section; a review of the literature to support the study; the methodological procedures of the research; and the results with discussion.

\section{LITERATURE REVIEW}

\section{What are the core competencies of the company?}

Albeit widely discussed in literature, this issue deserves a brief review. The idea of competence, initially forged in the individual level, has been present in works of authors of the organizational development area, which, in general, consider it a set of skills, conduct and knowledge that would point to a better performance of the individual (McClelland, 1973; Spencer \& Spencer, 1993; Mclagan, 1997). Despite some semantics disputes, soon there was an attempt to differentiate individual competence and other correlated individual attributes, such as capacity (potential developed by the individual in previous situations); ability (natural talent that may be improved); skill (clarification of a practical talent); and 
knowledge (what an individual needs to know to perform a specific task) (McClelland, 1973; Fleury, M.T.; Fleury, A., 2004). However, in the organizational level, the idea of competence seeks to be global, covering all these dimensions in a collective level. Therefore, it involves the availability of the company's set of tangible and intangible resources. Regarding the comprehensive nature of the organizational competence, Durand (1998) compares it to an organizational alchemy, stating that in medieval times alchemists sought to turn metals into gold; nowadays, companies and their executives seek to turn resources and assets into profits. For this purpose, a new type of alchemy would be necessary to companies, which is being called competence.

But it was really the seminal work of Prahalad \& Hamel (1990) - The Core Competence of the Corporation - that allows the idea of a company's core competence to be understood as intrinsically associated to the overarching strategy of the business, attracting the interest not only of researchers, but also of professionals responsible for developing strategies. As is widely known, the motivation for such study was the strong competition faced by North-American companies from the Japanese at the time, when circumstances made companies located in western USA, which had market dominance between the 1950's and 1970's, lose their market share to Japanese companies in a short time (1975-1985). The reasons why the productive and market leadership had changed so significantly in such a short period of time were questioned, since American companies had grown, in average, only $5 \%$, while Japanese companies grew $20 \%$ in the same period of time. The convenience of the study carried out by both authors soon became clear. Prahalad and Hamel's argument was that American companies were not using their greater resource, their core competence, in a strategic way.

Examining the interplay of firm resources, capabilities, and competencies, Rothaermel (2016) emphasizes that both must be present to possess core competencies essential to gaining and sustaining competitive advantage through strategy. According to Baczynska et al. (2016) the main advantage of the core competencies approach is that it recognizes the interaction of technology, skills and people that determines firm performance and addresses the importance of learning. The authors emphasize that core competencies have similar role in most organizations and that their number is, and should be, limited. The authors propose a core competency model which suits the needs of a rapidly changing market while at the same time taking into account "stability" and high standards of task performance in employee profiles. The authors proposed a dimension that is important in the majority of organizations: Ensuring the organization's competitive advantage on the market (entrepreneurial orientation), and linked it to core competencies.
Lastly, a warning made by Prahalad \& Hamel (1990) when debating on the benefits of competencies aligned to strategy is reiterated. It regards the risks of imitation and loss of exclusivity, especially those resulting from misdirected outsourcing of processes. If properly executed, outsourcing appears as a measure that allows the company to operate with structures that are more flexible, agile and committed to the main calling of the business. However, it may be a fairly risky process, in case the company does not have full knowledge of its core competence(ies), since it could transfer the ownership of this precious asset to a thirdparty, therefore decreasing the competitiveness of the business.

Another warning is made by Schaupp and Virkkunen (2017). The authors analyse the creation and use of the concept of a corporation's core competence. The analysis shows how a theoretical abstraction of a novel strategic principle turned into an "empirical abstraction", which in practice has triggered unproductive attempts to categorize existing competencies. This work is an attempt to fill this void.

\section{Aligning Core Competencies with Strategy: the effect on performance}

There are several studies linking the alignment of core competencies and corporate strategy to performance. Some of these are reviewed here.

Band and Scanlan (1995) argue that Toyota Motor Company had a focus on market leadership and tried to reach this leadership by intentionally investing heavily in competencies, partly by entering alliances that fit its strategic vision. They also point out that Nucor (a steel company) has developed core competencies in technological innovation, research and development, corporate culture and cost leadership. In their view, because of the strategic alignment of these competencies, the company became the leading US minimill steel producer. The authors also conclude that Gillete's lack of a strategic architecture temporarily undermined the company's prospects for sustainable competitive advantage, which it had regained, by 1995 , by refocussing on its traditional core competencies of strategic R \& D and branding.

Arslan and Ozturan (2011), in a quantitative study with a sample of 212 companies, proposed that information technology investments can deliver higher firm performance if they are used to support organizational core competencies. Based on the data collected, the authors show that IT support for core competencies has a significant positive effect on firm performance.

According to Fleury and Fleury (2003), in their empirical study based on a large sample of Brazilian firms, the efforts to increase competitiveness might demand a much larger amount of time and resources, especially those required for the creation of local competencies at an international level. Therefore, 
in the view of the authors, competitiveness is dependent on the alignment between the strategy to become internationalized with the core competencies of firms.

Ribeiro et al. (2009) studied Brazilian cell phone service companies and investigated how the process of formulating strategies based on core competencies is a determining factor of competition and leadership in the sector. The authors found that companies with a strategic focus on innovation (including those that innovate in terms of updating core competencies) seem to have a better performance in the market.

According to Heracleous and Werres (2016), little empirical research to date has examined the process leading to misalignment and eventual corporate failure over time. To explore this crucial link, the authors conducted case studies of two conglomerates. They found patterns in terms of factors through which misalignments develop, leading to bankruptcy. Gradually spreading organizational misalignments unfold, ultimately fostering a gap between the demands of the competitive environment and the corporate strategy and core competencies, leading to failure.

\section{METHOD}

This is an exploratory, descriptive and qualitative work, empirically based on a multiple case study that lasted six months. Therefore, the desire is not to confirm hypotheses, but to make an inductive approach, in the interest of proposing and operationalizing a methodology to map core competencies, particularly in an industry of consolidated technology (Eisenhardt, 1989; Yin, 2003).

In this section, a brief comment is made regarding the sample of companies, followed by the design of the empirical research.

\section{Sample}

For this study, intentional sampling was performed and the nine most important steelmaking companies associated to the Brazil Steel Institute (ABr) were chosen. Such companies belong to economic groups operating in 10 Brazilian states and were responsible for a joint production of almost 34 million tons of crude steel offered to the global market in 2014. Such companies fulfill almost the entire domestic demand for steel, producing a wide range of types of flat, long, semi-finished and finished products. Such products supply multiple sectors of the Brazilian economy.

The identities of the companies are not revealed due to confidentiality purposes, so they are identified by the letters A, B, C, D, E, F, G, H and I. For each company, some socio-demographic information (size, products, market) and strategies (strategic guidance, competencies, alignments, performance) obtained in the study is found in the section dedicated to the results of the research. Such information has been gathered from semi-structured interviews with executives at the senior management level and, also, from secondary sources, found in documents made available by IABr. Care was taken to triangulate the secondary data with the information obtained from the interviewees, to enhance coherence (Flick, 2005).

\section{Outline of the empirical work}

The research was outlined in three steps: (i) characterize the company's strategy; (ii) map the company's core competencies; and (iii) assess the alignment between core competencies and corporate strategy.

\section{Characterizing the Company's Strategy}

In the first step of the empirical work, strategic orientations of the companies were characterized, starting, at first, with the four dimensions of the performance evaluation model, by Kaplan \& Norton (2008). Such dimensions were expanded after initial debates with executives of the companies, resulting in a reference framework with seven major strategic interests (dimensions) typically observed in the steelmaking industry. Such dimensions are: market; financial; operations; quality; technology; supply chain; and HSE (health, safety and environment).

The empiric identification of core competencies in an operating company is a topic that does not seem to have been sufficiently detailed by the authors of the original concept, who were limited to the ex-post narratives (competencies already accomplished) and broad recommendations. Zook \& Allen (2010) were concerned about this aspect and wondered: how is the core competence of a company identified? By its products? By its intellectual properties? By its processes? Or by its business model? For some companies, this identification can be relatively simple; for others it is extremely complicated. For all companies it is very important that the identification is as clear as possible. Such authors also maintained that it is not possible to proactively manage a company if the senior management does not share the same vision regarding such competencies. Therefore, the clarity with which a company acknowledges its core competencies and the degree of agreement regarding this understanding in the company (deployment) would be the simplest tests of the capacity to manage core competencies. Although almost every manager realizes "what we do here" (Zook \& Allen, 2010), most of them may have some trouble tracing links between a specific set of productive skills and the competitiveness brought by the corresponding final products and services. Therefore, a basic task in organization would be a 
survey of such competencies. For that purpose, Zook \& Allen (2010) suggest that the following five aspects are mapped: the clients with greater profit potential; the most differentiated competencies and strategies; the most critical product offers; the most important channels; and any other key strategic assets that contribute to such aspects, such as, for instance, patents and trademarks.

Albeit important, such orientations still seemed vague for the empiric purpose of this work. It was in the study conducted by Hafeez, Zhang \& Malak (2002) that we found more objective orientations, from which a practical model for mapping core competencies was developed to assess this issue in Brazilian steelmaking companies, as will be seen ahead in this work. To identify core competencies, these three authors propose a methodology, shown as a scheme in figure 1, which consists of the following steps:

(a) Listing the wide set of global competencies of the company, which are disseminated in all of its functional areas and are supported by its physical, intellectual and cultural assets; (b) applying a "ubiquity filter" to these global competencies to select the set of the so called required competencies, that is, those deemed potentially necessary to execute the generic strategies of the business, and are disseminated throughout the company;

(c) applying, subsequently, the "exclusivity filter" to the required competencies, through which only the key competencies will pass, that is, those that are unique in nature and hard to copy by potential competitors; and lastly,

(d) submitting key competencies to the "flexibility filter", from which the few core competencies of the business will emerge. This last filter selects, among the key competences, only those that allow for the company to have the dynamic behavior that is crucial to offer valuable products/services in different markets and circumstances.

Figure 1 - Core competencies identification - methodology scheme

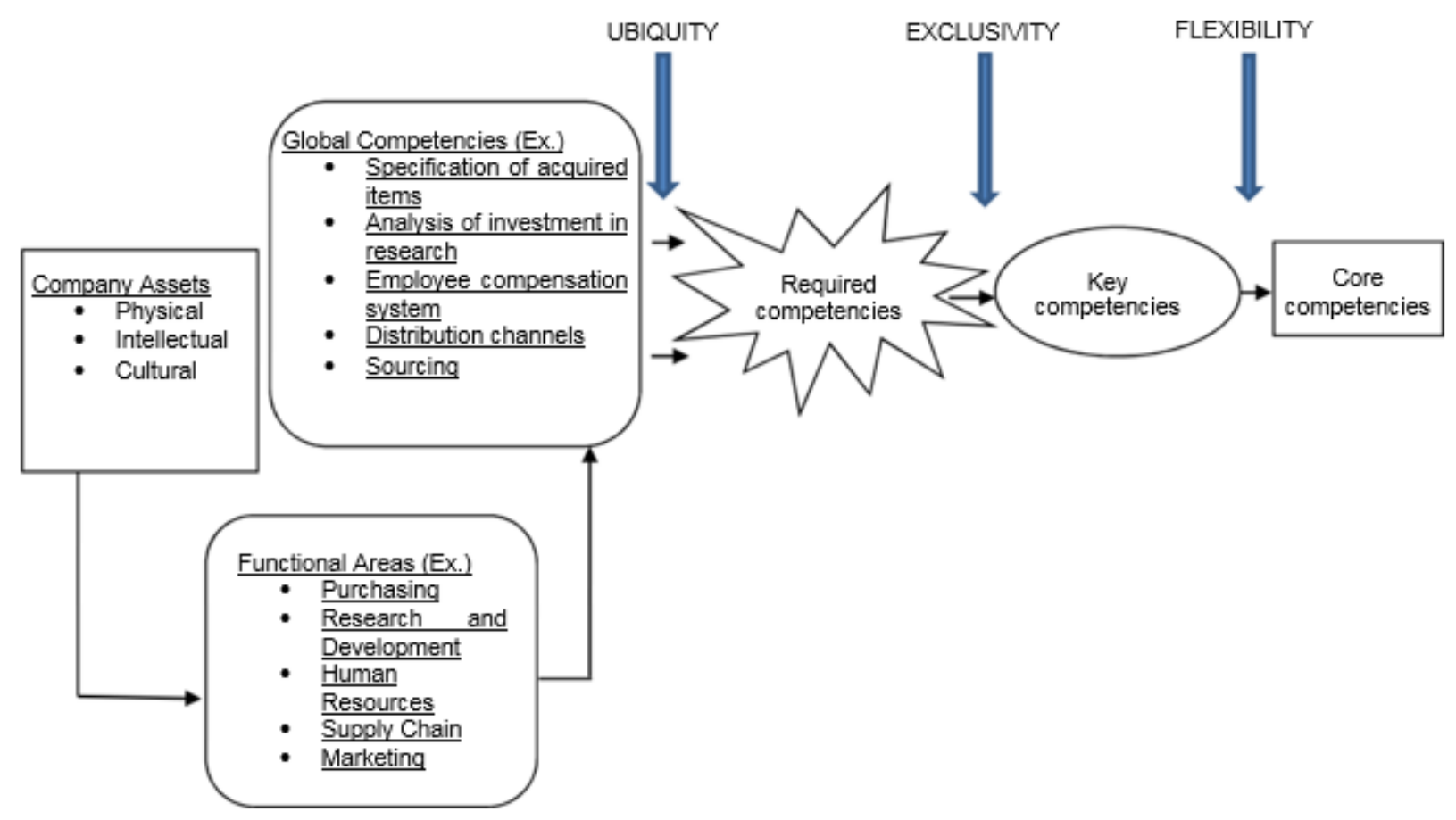

Source: Developed based in Hafeez; Zhang; Malak (2002)

It is noticeable that the three filters employed in the selection of core competencies ensure that they have a simultaneous commitment with the generic strategy of the business (ubiquity); the achievement of a value that is hard to copy (exclusivity); and with the use of such value in different products and markets (flexibility).

To identify core competencies based on this methodology, Hafeez, Zhang \& Malak (2002) were guided by the insights of the executives of the companies researched by them. Although ordinal scales 
and weighting factors are employed, it is known that this type of procedure is subject to natural biases and subjectivities. On the other hand, it is unlikely that there would be an objective procedure, free of uncertainties, for the ex-ante mapping of competencies in potential state associated to the business strategy. That study has the merit of systematizing the search for core competencies in the company, having inspired the methodology to identify the referred competencies in this work.

\section{Mapping of core competencies}

To execute the second step of the study, the global competencies listed by using the aforementioned model by Hafeez, Zhang and Malak (2002) were operationalized and tailored it to steelmaking companies (see scheme presented in figure 2). It was considered that the assets of the steelmaking companies are distributed in 10 main functional areas (purchasing; manufacturing; HSE; human resources; marketing; supply chain; research and development; business administration; maintenance; and quality). The choice of 10 functional areas did not take into account the hierarchical organizational structure and control of the companies. Our interest was focused exclusively in the definition of each locus that gathers groups of global competencies of the steelmaking company in general. In the set of the 10 functional areas, 33 global competencies expected for companies of the steelmaking industry were compiled.

The successive selection of "required", "key" and "core" competencies was performed, for each company, based on the method showed in figure 2. For such selection, the steps described below were adopted.

Figure 2 - Model to map core competencies

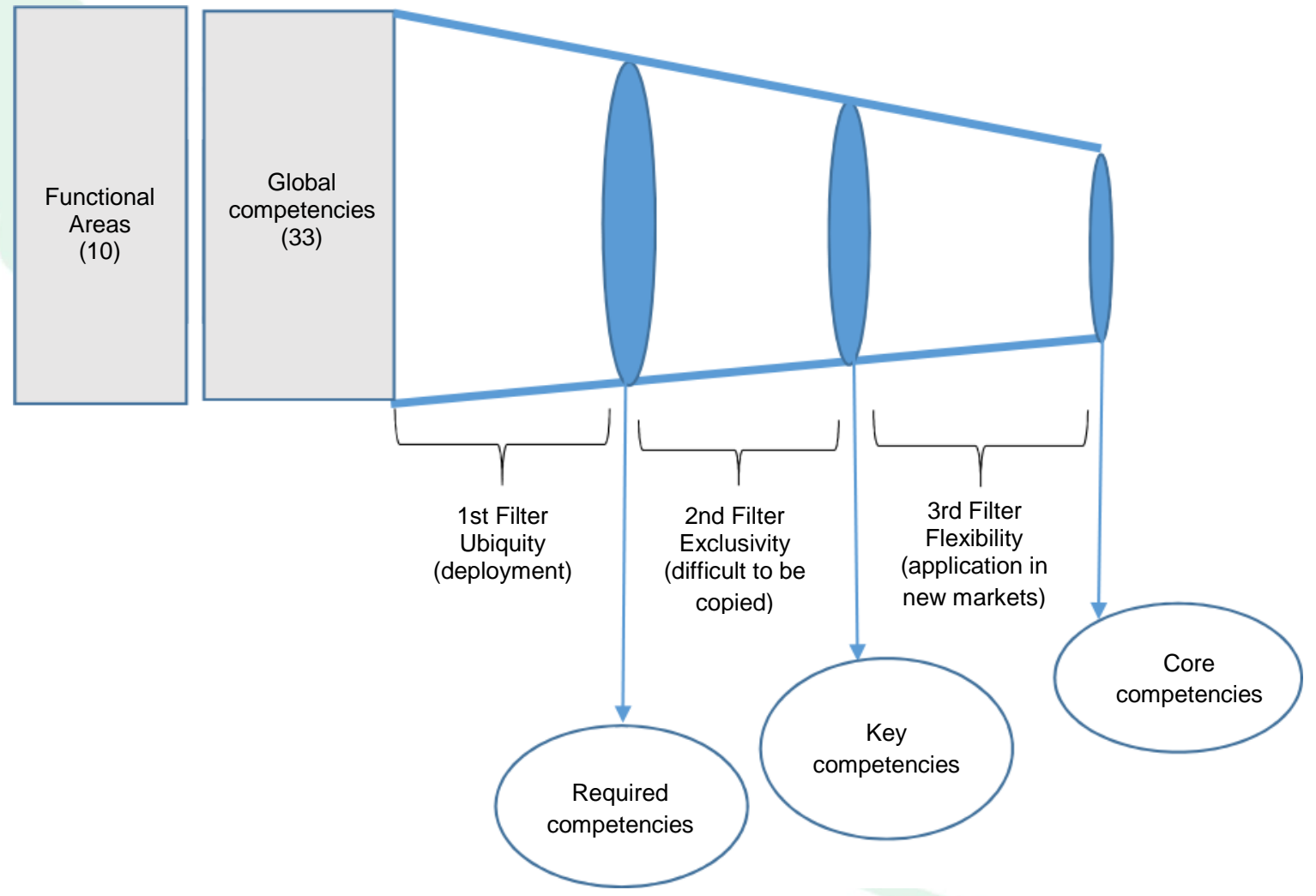

Note: developed by the authors based on the model by Hafeez; Zhang; Malak (2002)

- Application of the 1 st filter (ubiquity) to select the required competencies:

From the list of 33 global competencies previously established, each company was asked to select its required competencies with the participation of the executives that were interviewed using the ubiquity filter. This filter assessed the importance of each global competence to carry out the generic strategies of the business. For that end, those who were interviewed were requested to assess each of the 33 global competencies regarding their global strategic relevance, according to a Likert scale ranging from 1 to 4 , in the following order: 1 - "Very Little Relevance"; 2 - "Little Relevance"; 3 - "Relevant"; and 4 - "Highly Relevant". Only global competencies with scores 3 or 4 were deemed required competencies.

- Application of the 2nd filter (exclusivity) to select key competencies: 
The exclusivity filter was then applied to the required competencies previously chosen. For that end, the same interviewees were invited to assess each of the required competencies, regarding their relevance to the unit and difficulty on being copied, using the same proportional scale (from 1 to 4 ) that was previously employed. The required competencies with scores 3 or 4 were then named key competencies and qualified for the third and last filter.

- Application of the 3rd filter (flexibility) to select core competencies.

Lastly, the flexibility filter was applied to the key competencies, to select the core competencies. The respondents were then asked to assess each key competence regarding their relevance to flexibility, that is, their relevance to generate new products intended for new markets. The same scale that had been used so far was employed. In this last step only the key competencies that scored 3 or 4 were deemed core competencies.

For this procedure, the (few) core competencies of each sample company were mapped, as shown in the results section.

Assessment of the strategic alignment of core competencies

For the third step of the field work, a square matrix that reflects the alignment of core competencies with the respective strategies of the companies was built. The strategies formed the columns of the matrix and the core competencies comprised lines. While building the matrix, the group of competencies (lines) and respective strategic dimensions (columns) were represented so that in the resulting square matrix the companies with full alignment between the core competencies and the strategies occupy the matrix's descending diagonal, as will be seen and explained in the following section, in which the results of the research will be presented.

\section{RESULTS}

This section will present the results of the study, beginning with the strategic orientations that were detected.

\section{Strategic orientations of the companies}

Information regarding the nine companies can be found in Appendix 1, where a brief description of the companies and their respective strategic orientations detected by the researchers is presented. Such information was obtained in the interviews with professionals and triangulated with secondary data provided by $\mathrm{IABr}$.

In the outline of the companies' strategies characterization (Table 1), it can be noticed that the market (companies A, B, F and G) and technological (companies $\mathrm{C}, \mathrm{D}, \mathrm{E}$ and $\mathrm{H}$ ) dimensions occur more often.

Table 1 - Outline of the companies' strategies - orientations detected

\begin{tabular}{|l|c|}
\hline $\begin{array}{c}\text { Strategic Orientation } \\
\text { detected }\end{array}$ & Companies \\
\hline Market & A B F G \\
\hline Financial & C \\
\hline Operation & I \\
\hline Quality & H D E H \\
\hline Technology & F \\
\hline Supply Chain & A B I \\
\hline HSE & \\
\hline
\end{tabular}

Source: The authors

\section{Mapping of Core competencies}

Table 2 shows the information regarding the mapping of the companies' core competencies. 
Table 2- Result of the mapping of the companies' core competencies

\begin{tabular}{|c|c|c|c|c|}
\hline & & & COMPANIES & \\
\hline Functional Area (10) & Global Competencies (33) & Required Competencies & Key Competencies & $\begin{array}{c}\text { Core } \\
\text { Competencies }\end{array}$ \\
\hline & Specification Definition & A C F & A C F & \\
\hline & $\begin{array}{l}\text { Negotiation of Commercial } \\
\text { Conditions }\end{array}$ & A B D G I & A B G & \\
\hline PURCHASING & Speed in acquisition & & & \\
\hline & Generation of Savings & A CDEFGH I & C D F G H I & G \\
\hline & Qualification of Suppliers & A C G I & C G & \\
\hline & Process technology & A B CDF G & CDF G & \\
\hline & Machine set up & AD H & $\mathbf{H}$ & $\mathbf{H}$ \\
\hline MANUFACTURING & Production batch & A B D E H & E H & E H \\
\hline & Productivity & A B CDEFGI & A B CDEF G I & E G I \\
\hline & Production capacity & A B E F H & A B & \\
\hline & Level of Accidents & A B D E F G H I & D G I & \\
\hline AND ENVIRONMENT & \begin{tabular}{|l|} 
Environmental \\
Sustainability \\
\end{tabular} & A B C E G I & A B I & A B I \\
\hline & Compensation Policy & A C E F G H & $\mathbf{H}$ & \\
\hline & Training Policy & A CEFH I & A H I & \\
\hline HUMAN KESUUKCES & Benefits Policy & D F G H & & \\
\hline & Talent retaining & H I & $\mathbf{I}$ & \\
\hline & Sourcing & A B C G & A B G & A B \\
\hline MARKFTING & Advertising & & & \\
\hline MAKKE TING & Sale Price & A B C D G & A C & $\mathbf{C}$ \\
\hline & After-Sales Service & B D F G & F G & $\mathbf{F}$ \\
\hline & Distribution Channel & A B D E F G H I & A B F G H I & F I \\
\hline SUPPLY CHAIN & Foreign Trade - Export & $\mathbf{A ~ G}$ & $\mathbf{G}$ & \\
\hline & Foreign Trade - Import & $\mathbf{A}$ & & \\
\hline & $\begin{array}{l}\text { Qualification of Technical } \\
\text { Staff }\end{array}$ & C & C & C \\
\hline $\begin{array}{l}\text { RESEARCH AND } \\
\text { DEVELOPMENT }\end{array}$ & $\begin{array}{l}\text { Investment in } \\
\text { research/equipment }\end{array}$ & A B C D & A C D & C D \\
\hline & Experiments & CD & C D & D \\
\hline & Goal setting & A D G & & \\
\hline BUSINESS & Result monitoring & F G & & \\
\hline ADMINISTRATION & \begin{tabular}{|l} 
Recognition and Award \\
System
\end{tabular} & D F I & I & \\
\hline & Equipment Reliability & E F G H & E F H & $\mathbf{H}$ \\
\hline MAINTENANCE & \begin{tabular}{|lll}
$\begin{array}{l}\text { Planning of Scheduled } \\
\text { Stops }\end{array}$ & \\
\end{tabular} & E F H & $\mathbf{E}$ & \\
\hline & Equipment Uptime & E F H & $\mathbf{E}$ & \\
\hline QUALITY & Product quality & A B C EGH I & E G I & E I \\
\hline
\end{tabular}

A first general analysis reveals that the most common core competencies among the companies are: Productivity, occurring in companies E, G and I; and Environmental Sustainability, which occurs in companies A, B and I. None of the competencies associated with the Business Administration function was deemed as a core competence, which also occurred with the Human Resources area. Companies A and B were the only ones to elect Sourcing as a core competence to the business. Companies $\mathrm{C}$ and $\mathrm{D}$ are the only ones that indicated as core competencies those arising from the Research and Development functional area. Since strategic orientations focused on Marketing and Technology were found more often in the sample, it is clear that some of the companies show an alignment of their core competencies with the respective strategic orientations, and some don't.

Verification of the strategic alignment of core competencies

In order to facilitate the explanation and visualization of the strategic alignment of competencies in the nine companies, the square $6 \times 6$ 
matrix (Table 3) was used, in which the columns indicate the strategic dimensions detected, and the lines indicate the core competencies mapped. The financial dimension does not appear in the matrix, as it was not initially considered among the 33 global competencies expected for a steelmaking company.

Furthermore, it was subsequently found that the competence in Savings while purchasing, for company G, was applicable to the Supply Chain dimension. Therefore, the 12 mapped core competencies appear in the lines of the matrix, grouped in 6 sets, corresponding to the respective functional areas from which they arise. These six sets of core competencies are arranged according to the six strategic dimensions, respectively.
The companies that show full alignment between core competencies and respective strategies are those positioned exclusively in the descending diagonal of the matrix. Companies A, B, D and F are fully aligned (Table 3 ). In contrast, there are companies whose core competencies are completely out of line with their strategies. Such companies are always outside the diagonal of the alignment matrix. Companies E, $\mathrm{G}$ and $\mathrm{H}$ are in this situation. Finally, there are companies whose core competencies are partially aligned with their strategies, that is, they appear both in the matrix's diagonal and outside of it. Such is the case of companies C and I.

Table 3 - Strategic alignment of core competencies

\begin{tabular}{|c|c|c|c|c|c|c|c|c|}
\hline & \multicolumn{6}{|c|}{ STRATEGIC DIRECTION } \\
\hline & & & Market & Operation & Quality & Technology & $\begin{array}{l}\text { Supply } \\
\text { Chain }\end{array}$ & HSE \\
\hline \multirow{11}{*}{ 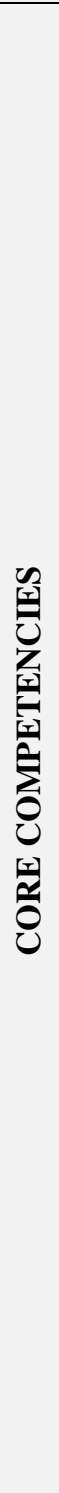 } & \multirow{3}{*}{ 离 } & Sourcing & A, B & & & & & \\
\hline & & Sale Price & & & & $\mathrm{C}$ & & \\
\hline & & $\begin{array}{l}\text { After-Sales } \\
\text { Service }\end{array}$ & $\mathbf{F}$ & & & & & \\
\hline & \multirow{3}{*}{ 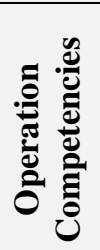 } & Machine set up & & & & $\mathrm{H}$ & & \\
\hline & & Production batch & & & & $\mathrm{EH}$ & & \\
\hline & & Productivity & G & I & & $\mathbf{E}$ & & \\
\hline & 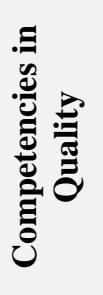 & Product Quality & & & I & $\mathbf{E}$ & & \\
\hline & \multirow{2}{*}{ 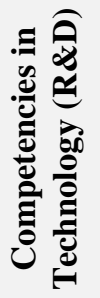 } & $\begin{array}{l}\text { Investment in } \\
\text { research }\end{array}$ & & & & $\mathbf{C}, \mathbf{D}$ & & \\
\hline & & Experiments & & & & D & & \\
\hline & \multirow{2}{*}{ 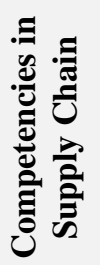 } & $\begin{array}{l}\text { Distribution } \\
\text { Channel }\end{array}$ & & & & & $\mathbf{F}$ & I \\
\hline & & $\begin{array}{l}\text { Generation of } \\
\text { Savings }\end{array}$ & G & & & & & \\
\hline
\end{tabular}




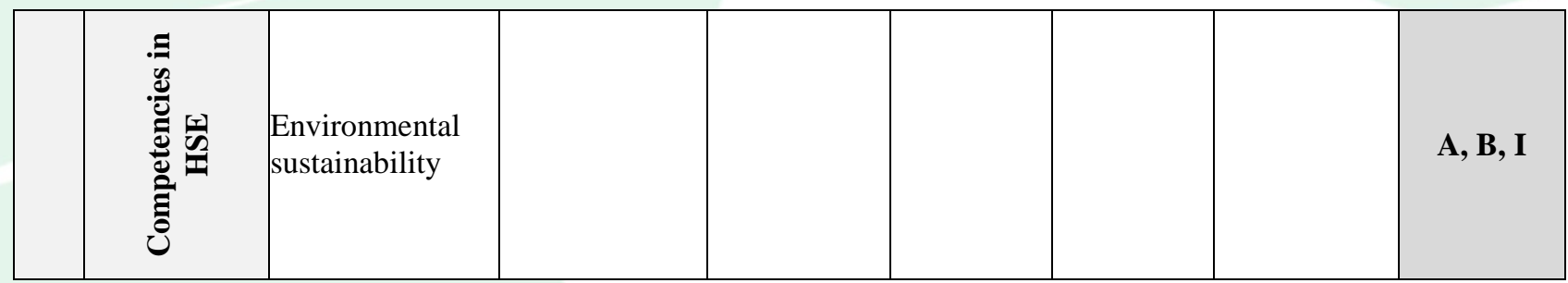

Note: matrix resulting from the intersection between mapped core competencies and strategic dimensions detected.

The sample was divided into three groups: I large, aligned companies (A, B, D and F); II - small, partially aligned companies (C and I); and III - small, out of line companies (E, $\mathrm{G}$ and $\mathrm{H})$.

\section{DISCUSSION}

At this point, it is considered that the question raised by the study - that is, the inquiry regarding the strategic alignment of the core competencies of steelmaking companies in the country - has been answered with the employment of the methodology developed. There are a few comments left regarding the three groups of the sample companies, which differ from each other as to the degree of alignment.

Group I - large, aligned companies:

This group is comprised by companies A, B, $\mathrm{D}$ and $\mathrm{F}$ that control about $82 \%$ of the national steel market and showed full alignment between core competencies and strategies. These four companies share the common characteristic of having as their primary focus the steelmaking business. They have several manufacturing plants in the country and in the world, and have their main source of revenue in the production of steel. The market share of these companies is significantly larger, compared to the market share of the companies in the other groups.
Higher market share puts companies at a competitive advantage. Companies with high market share often receive better prices from suppliers, as their larger order volumes increase their buying power. Also, increased market share and greater production go handin-hand, with the latter decreasing a company's cost to produce an individual unit due to economies of scale. All these factors contribute to increase profitability (Szymanski et al., 1993) This superior performance of the "aligned firms" is in line with empirical evidence (Ribeiro et al., 2009; Band and Scanlan, 1995; Arslan and Ozturan, 2011; Fleury and Fleury, 2003; Heracleous and Werres, 2016).

Due to their economic power, these companies belong to the small group of companies that, in the past decade, made significant purchasing, merger and incorporation maneuvers in the steelmaking industry. It is worth mentioning that, regardless of not having increased their market share in the past years, four companies of Group I have not had losses, and kept their controlling positions (Table 4 and Figure 3). This indicates a relative stability in competition, although one cannot claim that the maintenance of such positions is exclusively due to the strategic alignment of core competencies in the companies of Group I. Other factors, not identified in this study, may have influenced the stability of the market leadership.

Table 4 - Evolution of the companies' market share, \% (from 2011 to 2014)

\begin{tabular}{c|c|c|c|c|c}
\hline Company & $\mathbf{2 0 1 1}$ & $\mathbf{2 0 1 2}$ & $\mathbf{2 0 1 3}$ & $\mathbf{2 0 1 4}$ & Average, \% \\
\hline $\mathbf{A}$ & 24.8 & 24.9 & 23.7 & 23.6 & 24.3 \\
\hline $\mathbf{B}$ & 30.7 & 27.5 & 24.7 & 25.4 & 27.1 \\
\hline $\mathbf{C}$ & 1.7 & 1.6 & 2.0 & 2.1 & 2.9 \\
\hline $\mathbf{D}$ & 22.2 & 19.0 & 20.7 & 20.1 & 20.5 \\
\hline $\mathbf{E}$ & 4.4 & 4.0 & 5.4 & 4.6 & 4.6 \\
\hline $\mathbf{F}$ & 14.9 & 13.8 & 14.0 & 13.0 & 13.9 \\
\hline $\mathbf{H}$ & 3.2 & 3.1 & 3.3 & 3.5 & 3.3 \\
\hline $\mathbf{I}$ & 2.3 & 2.4 & 2.5 & 2.5 & 2.4 \\
\hline
\end{tabular}

Source: Brazilian Steel Institute 
Figure 3 - Average domestic market share, from 2011 to 2014

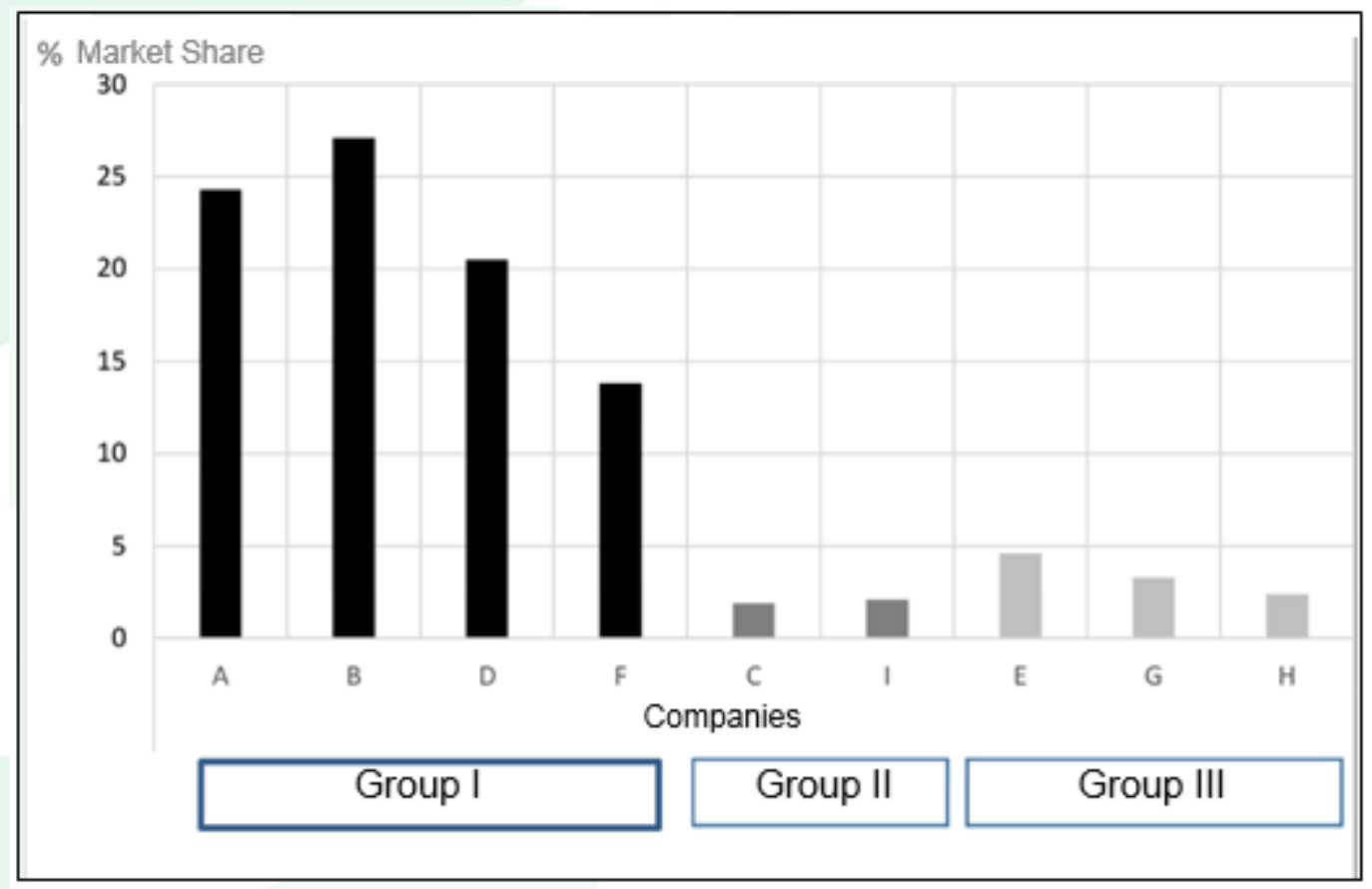

Source: The authors, based on table 4 .

Group II - small, partially aligned companies:

The two companies in Group II - C and I have only $4 \%$ of the domestic market share, since they own plants with lower capacity in the country (Table 4 and Figure 3). However, both companies have a good understanding of the parent corporation's organizational strategy and, therefore, have core competencies largely aligned with the corporate strategies. However, it can be noted that local units are deeply concerned with operational performance issues. While this option may not be considered in the corporate strategies, it seems correct. Because manufacturing plants in Brazil face, in addition to the competition of their peers in Group I, a strong intercompany competition from plants owned by the same economic group located in other countries, they therefore, have to be self-sufficient, which is made easier due to the good local performance in productivity.

Group III - small, out of line companies:

The group comprised by companies E, G and $\mathrm{H}$ totals around $10 \%$ market share in the domestic steel market (Table 4 and Figure 3). These three companies have shown a complete lack of alignment between core competencies and strategies. They focus, primarily, in traditional manufacturing performance issues, in detriment of the technologic orientation showed by the corporations to which they belong. This preferred search for reduction of production costs and increase in productivity guides the actions taken by such companies. An observation that proved to be relevant is that the "steel business", in which these three companies participate, represents a very small part of the revenue generation of the large economic groups to which they belong. This explains why the strategies developed by the parent corporate groups of such companies do not benefit from the core competencies identified in local units, isolating them from the corporations, and, therefore, weakening them.

Lastly, it was found that company E outsources one of its core competencies: its product inspection; and company $\mathrm{H}$ outsources production equipment maintenance, which is deemed a core competence to its business.

\section{CONCLUSION}

The fully or partially "aligned" companies (Groups I and II) control around $86 \%$ of the Brazilian steel market, and have kept this share stable in the past five years. By the technologic content of some competencies associated to strategies, these companies seem more fit to the current competition than the "out of line" companies, which show lower potential to the development of new products for other markets.

Although the study allows for this initial analysis, the greatest contribution of this work is in operationalizing a methodology to map core competencies and corporate strategy, and to evaluate their degree of alignment. These concepts are widely found and explored in the literature, but are difficult to operationalize in the companies' daily activities. Such a 
simple, but precise methodology might be useful for companies that need to evaluate and/or formulate their corporate strategies in a more effective manner, by following a widely known and important theoretical concept, i.e. the alignment between core competencies and corporate strategy.

The conclusions of this study are based on the insights of the people who were interviewed, and, therefore, may be biased. The employment of more robust tools to address insights from individuals, such as the Analytic Hierarchy Process - AHP, would reduce such fragility, and is currently being considered to further improve the methodology proposed in the study.

\section{REFERENCES}

Arslan, B., Ozturan, M. (2011). The Path to Information Technology Business Value: Case of Turkey. Technology and Investment 2, 52-63.

Baczynska, A.K., Rowinski, T., Cybis, N. (2016). Proposed Core Competencies and Empirical Validation Procedure in Competency Modeling: Confirmation and Classification. Frontiers in Psychology, Vol. 7, article 273, pp.1-13.

Barney, J.B. (1991). Firm resources and sustained competitive advantage. Journal of Management, vol. 17, n. 1, pp. 99-120.

. (1995). Looking inside for competitive advantage. Academy of Management Executive, vol. 9, issue 4, pp. 49-61.

Band, D.C., Scanlan, G. (1995). Strategic Control through Core Competencies. Long Range Planning, Vol. 28, No. 2, pp. 102-114.

Crossetti, P. D. A.; Fernandes, P. D (2005). Para onde vai a China? O impacto do crescimento chinês na siderurgia brasileira. BNDES Setorial, v.22, pp.151204.

Danilovic, M.; Leisner, P. (2007). Analysing core competence and core products for developing agile and adaptable corporation. Proceedings of the $9^{\text {th }}$ Dependency Structure Matrix (DSM) International Conference, 16-18 october 2007, Munich, Germany.

Durand, T. (1998). Forms of incompetence. Conference on Management of Competence, Oslo.

Eisenhardt, K. M. (1989). Building theories from case study research. Academy of Management Review, 14(4), pg. 532-550.
O Estado de S. Paulo. (27/11/2015). Crise na siderurgia fecha 29 mil vagas em cerca de 2 anos. Caderno de Economia B13.

. (02/01/2016). Siderurgia prevê mais um ano de retração em 2016. Caderno de Economia B5.

Fleury A., Fleury, M.T. (2003). Competitive strategies and core competencies: perspectives for the internationalisation of industry in Brazil, Integrated Manufacturing Systems, Vol. 14 Issue: 1,pp. 16-25,

Fleury, M.T.; Fleury, A. (2004). Alinhando estratégia e competências. RAE - Revista de Administração de Empresas FGV/EAESP, vol.44, n.1, pp.47-57.

Flick, U. (2005). Triangulation in Qualitative Research. In: Flick, U., Kardorff, E., \& Steinke, A. Companion to Qualitative Research. London: Sage, 178-183.

Grant, R.M. (1991). The resource-based theory of competitive advantage: implications for strategy formulation. California Management Review, spring, pp. 114-135.

Hafeez, K; Zhang, Y; Malak, N. (2002). Core Competence for Sustainable Competitive Advantage: a structured methodology for identifying core competence. IEEE Transactions on Engineering Management, vol. 49, n. 1, February, pp. 28-35.

Instituto Aço Brasil (2015). A Siderurgia em números 2014. Rio de Janeiro: 2015

. Sustainability report 2014. Available at:

<http://www.acobrasil.org.br/site/portugues/sustentabil idade/downloads/Relatorio $\% 20$

de\%20Sustentabilidade_2014_web.pdf >. Accessed on: Mar.2015.

. Sustainability report 2013. Available in:

<http://www.acobrasil.org.br/site/portugues/sustentabil idade/downloads/relatorio_sustentabilidade_2013v3 .pdf>. Accessed on: Mar.2015.

. Sustainability report 2012. Available in:

<http://www.acobrasil.org.br/site/portugues/sustentabil idade/downloads/relatorio_sustentabilidade_2012.p df>. Accessed on: Mar.2015.

Hafeez, K; Zhang, Y; Malak, N. (2002). Core Competence for Sustainable Competitive Advantage: a structured methodology for identifying core competence. IEEE Transactions on Engineering Management, vol.49, n. 1, February, pp. 28-35. 
Heracleous, L., Werres, K. (2016). On the Road to Disaster: Strategic Misalignments and Corporate Failure. Long Range Planning, Vol. 49, pp. 491506.

Instituto Aço Brasil (2015). A Siderurgia em números 2014. Rio de Janeiro: 2015

Relatório de sustentabilidade 2014. Disponível em:

<http://www.acobrasil.org.br/site/portugues/sustentabil idade/downloads/Relatorio $\% 20$

de\%20Sustentabilidade_2014_web.pdf $>$. Acesso em: Mar.2015.

. Relatório de sustentabilidade 2013. Disponível em:

<http://www.acobrasil.org.br/site/portugues/sustentabil idade/downloads/relatorio_sustentabilidade_2013v3 .tabilidade_2012.pdf>. Accessed on Mar.2015.

Kaplan, R.; Norton, D. (2008). The Execution Premium: linking strategy to operations for competitive advantage. Harvard Business School Press.

Mcclelland, D C. Testing for competence rather than intelligence. American Psychologist, n. 28, p. 1-4, 1973.

Mclagan, P. A. (1997). Competencies: The next generation. Training and Development, May, pp. 40-47.

Nonaka, I; Takeuchi, H. (1995). The knowledgecreating company. New York: Oxford University Press.

Penrose, E.G. (1959). The Theory of the Growth of the Firm. New York: Wiley.

Prahalad, C.K.; Hamel, G. (1990). The core competence of the corporation. Harvard Business Review, pp. 79-91, May-June.
Ribeiro, J.A., Goncalves, C.A., Souza, G.F.M., Borges, F.R.F., Barakat, L.L., Veiga, R,T. (2009). Competências essenciais como fator determinante de competitividade em ambientes hipercompetitivos: um estudo do setor de telefonia celular de Minas Gerais. Revista de Gestão USP, São Paulo, v. 16, n. 1, p. 51-67.

Rothaermel, F. (2016): Competitive Advantage in Technology Intensive Industries, in Marie C. Thursby (ed.) Technological Innovation: Generating Economic Results (Advances in the Study of Entrepreneurship, Innovation \& Economic Growth, Volume 26) Emerald Group Publishing Limited, pp.233 - 256.

Schaupp, M., Virkkunen, J. (2017). Why a management concept fails to support managers' work: The case of the 'core competence of a corporation'. Management Learning, Vol. 48(1) 97-109.

Spencer, L. M.; Spencer, S. M.(1993). Competence at work: models for superior performance. New York: John Wiley \& Sons.

Szymanski, D. M., Bharadwaj, S. G., \& Varadarajan, P. R. (1993). An analysis of the market shareprofitability relationship. The Journal of Marketing, 1-18.

Valor Econômico. (28/01/2016). Gerdau muda estratégia e anuncia joint venture. Página B1.

Wernerfelt, B. (1984). A resource-based view of the firm. Strategic Management Journal.vol. 5, pp.171180.

Yin, R. K. (2003). In: Case Study Research: Design and Methods. Sage Publications: Thousand Oaks, Ca., USA.

Zook, Chris; Allen, James (2010). Lucro a partir do core business. Rio de Janeiro: Elsevier. 


\section{APPENDIX 1 - Companies' strategic orientation}

\section{COMPANY A}

Leader in the segment of long steel in the Americas and one of the main suppliers of long steel in the world, with an installed capacity of approximately 25 million tons of steel per year. The company has 10 plants in Brazil, located primarily in the Southeast region. It features an integrated operation, and has a domestic market share ranging between $24 \%$ and $25 \%$.

\section{Strategic Orientation}

It was found that company A prioritizes the increase in market share, by searching for new business opportunities inside and outside Brazil, and improves the convergence of such orientation with environmental sustainability programs.

\section{COMPANY B}

Company $B$ is a multinational industrial conglomerate of steel companies, with a capacity of 130 million tons of steel per year, which represents $10 \%$ of the world market. In Brazil, there are 6 units, with a product portfolio that includes flat, long and stainless steel. It features an integrated operation. Company $B$ has had a domestic market share ranging from $25 \%$ to $31 \%$ in the past years.

Strategic Orientation

Increase of market share through the search for new business opportunities in Brazil and abroad, and maintenance of environmental sustainability actions were the most significant strategic trends identified by the research.

\section{COMPANY C}

The corporation to which company $C$ belongs is a world leader in the manufacturing of special tubular elements, supplying mostly to the energy market (oil and gas). Specialized in applications of greater complexity, it invests continuously in the 6 international research and development centers of the group. In Brazil, the corporation has a single manufacturing unit, company $C$, located in the Southeast region, with a lamination capacity of 600 thousand tons of seamless steel tubes. Company $C$ has a research center in the country, which focuses in the development of materials intended for the pre-salt oil exploration. It features an integrated operation, focusing on a niche and with a market share that varies from $1.5 \%$ to $2 \%$ of the domestic market.

Strategic Orientation

Company $\mathrm{C}$ focuses its strategy in the development of new technologies, specializing in complex local applications that enhance its competitiveness with clients and, following the corporation's orientation, keeps transparency in its relationship with the financial market.

\section{COMPANY D}

Company $D$ leads the production of cold and hot rolled flat steel, coils, plates and coated steel, intended for manufacturing capital goods, consumer goods and cars. It is located in the Southeast region, where it is renowned for having the greatest flat steel mill complex in Latin America. Its annual capacity exceeds 6 million tons of crude steel, manufactured in two units in Brazil.

The company has a Technology Center for the development of new steel products and enhancement of production processes. These efforts are supported by a network of 15 laboratories located within the plant. It features an integrated operation. Company $D$ has a market share that varies from $19 \%$ and $22 \%$ of the domestic market.

Strategic Orientation

Continuous improvement of its products and processes, in order to distinguish itself from the competitors was the core strategy identified for company D.

\section{COMPANY E}

Company $E$ belongs to an international conglomerate with more than 600 companies spread in 80 countries, and focus on three primary segments: steel, capital goods and services. The capital goods and services units manufacture elevators, parts for the automotive industry and assembly of plants for high technology industries. Its only steelmaking plant is located in the Southeast region of the country, and has a semi-integrated operation to manufacture products ranging from steel to carbon and stainless products. Over the past years, company $E^{\prime}$ 's domestic market share varied from $4 \%$ to $5 \%$.

Strategic Orientation

The international group to which Company $E$ belongs values investments in innovation and technology, focusing on products that add premium value to the client and, thus, ensure market expansion.

\section{COMPANY F}

Company $F$ belongs to an integrated complex, which operates in the steel making, mining, logistics, cement and energy sectors. Its operation is predominantly domestic, but it has plants in Europe and in the United States. It has an annual production capacity of 6 million tons of crude steel and 5 million tons of rolled steel per year. It is considered one of the most productive steel making companies of the world, and controls logistics companies that operate in a multimodal manner, with emphasis in transporting the iron ore extracted from the mines located in the country. Company $F$ has kept a relatively expressive domestic market share, ranging, in past years, from $13 \%$ to $15 \%$.

Strategic Orientation 
It was noted that the expansion to new markets, supported by a strengthened supply chain and service capacities, characterize the strategic orientation of company $F$.

\section{COMPANY G}

Company $G$ operates in more than 15 countries, spread across five continents, operating about 650 business units. It operates, globally, in industrial activities in the steelmaking, cement, metals, energy and cellulose areas. In Brazil, it has its own logistics system, in addition to possessing hydroelectric power plants capable of meeting $70 \%$ of the energy demand of its operations. In its portfolio, steel represents only the third largest revenue generator, behind cement and metals, which represent, together, almost $80 \%$ of such revenues. In the domestic steel sector, company $G$ features a semi-integrated operation in two plants located in the Southeast region, with a domestic market share that varies from $3 \%$ to $3.5 \%$.

Strategic Orientation

It was found that the organization strategy is based in the expansion of its international markets, in order to maximize the group's market share, as a whole, by its different business segments, making it globally competitive, in a sustainable manner.

\section{COMPANY H}

Company $H$ belongs to an international group that operates in the steel sector primarily by means of products for the mobility and energy industries. It is a semi-integrated plant, located in the Southeast region of Brazil, known for operating in a very specific segment of special high alloy non-flat steel. In its client portfolio, there are industries that demand high technology, such as aviation, automotive, hospitals and surgical implants. It has the support of its own research and development center.

Due to the niche it occupies, company $H$ has had a domestic market share varying from $2.3 \%$ to $2.5 \%$ in the past years. Strategic Orientation

It was found that, for company $H$, the existence of a strategic intent characterized by a combination of excellence in technology (new products) and leadership in quality, as a way to distinguish itself from its competitors.

\section{COMPANY I}

Company I was initiated its activities in the early 2000 's, becoming the largest steelmaking company located in the North/Northeast region of Brazil, with a production capacity of 400 thousand tons of rolled steel per year. It has its own fleet of compactor trucks that make clusters of scrap, which constiture its main raw material. It also processes ore, dedicating its production to the domestic market. It has a significant participation in the economic growth of the region where it is located. Since it depends on an effective scrap (raw material) supply system and on the local distribution of its products, the company identifies logistics as a relevant feature for the success of the business. Company I, due to its size and nature, has had a modest share in the national market, fluctuating, in past years, around $2 \%$.

Strategic Orientation

Operational excellence, product quality and environmentally sustainable activities were detected as strategic orientations of company I. The research has also identified signs of interest in the development of human resources.

Source: The authors 